\title{
Globalization Strategies and the Prospects of Increased Competition in the International Airline Industry
}

\author{
Scott E. Tarry and Lawrence J. Truitt
}

Southern Illinois University at Carbondale

\begin{abstract}
As governments debate open skies agreements, airlines are often left to find strategies that allow them to survive while waiting for a more liberal trading regime for international air travel. Airlines present an interesting theoretical case because they fail to conform to generally held notions about firm demands for protection or liberalization. The primary confounding factor in analyzing airline behavior is the pursuit of globalization strategies. This paper examines the potential impact of globalization strategies on competition in the international airline market. The conclusion from our initial analysis of four cases is that globalization strategies are reasonable for some airlines, but such strategies may actually lessen the chance for real competition in the market even if ongoing governmental negotiations are successful.
\end{abstract}

\section{Introduction}

It is often assumed that globalization and liberalization go hand in hand in the international economy. This thinking is based on the notion that as markets and firms become more global, political pressure for liberal trading arrangements increases.

Multinational firms, international joint ventures, and export dependent firms are expected to push for open access to markets. On its face, this seems to suggest that such firms are willing to accept more competition in exchange for access to new markets and fewer barriers to trade. By linking these expectations and assumptions some scholars and policy makers conclude that globalization strategies and liberalization policies are complementary steps towards the larger goal of a competitive free market international economy.

This paper examines these assumptions and expectations more closely through an analysis of the international airline market. We find that standard expectations about firm preferences for liberal trading arrangements generally do not hold. Moreover, we conclude that the push for globalization in the airline industry is a product of forces that are not commonly associated with liberalization, but rather those forces normally associated with protectionism and anti-competitive behavior. Finally, we offer a general model for understanding how firms devise strategies and attempt to influence policy while trying to maintain a credible market presence under increasingly fierce competition.

The standard hypotheses concerning firm-level preferences for liberalization or protection are inadequate when applied to the international airline industry. In contrast to the conclusions drawn from studies of other industries, we find no clear relationship 
between firm health and demands for protection. Where the traditional hypothesis suggests declining firms should seek protection, we observe that trade policy preferences and commercial strategies adopted by various airlines do not follow the expected course. Similarly, we find that levels of multinationality and export dependence do not necessarily lead firms to prefer more liberal trade strategies.

The reasons for this mixed bag of trade policy preferences and commercial strategies can only be explained by expanding the analytic lens to include changes in governmental policy, market structure, and technological innovation in the airline industry. Specifically, our examination of the U.S.-European international airline market confirms that the political processes that opened up the American domestic market are working towards opening the European Union market and the Transatlantic market as well, albeit at a more cautious and deliberate pace. We identify additional factors in the debate over liberalization of the international airline market and show why these must be incorporated into the analysis of both firm trade policy preferences and the prospects for further liberalization of the global air transportation market.

\section{Firm-Level Preferences for Trade Liberalization or Protection}

A popular approach to understanding trade policies is to examine the interests or preferences of firms. The basic assumption of this approach is that firms generate preferences for trade policies and attempt to influence governmental decision makers accordingly. The theoretical foundation for this work is rooted in the literature on endogenous tariff theory (Magee, Brock, and Young, 1989; Brock and Magee, 1978; Baldwin, 1986) and firm preferences for trade policies (Odell and I. M. Destler, 1987; Milner, 1988). This literature spans both political science and economics (Nelson, 1988; and Magee, 1994).

Three important hypotheses derive from the theory of firm preferences for trading policies. Firms experiencing a decline in profits, a deteriorating market share or other maladies will prefer protectionism (Hillman, 1982). Firms that rely on international markets or exports for the bulk of their business are more likely to oppose protection and favor liberalization (Ferguson, 1984). Finally, intrafirm trade among multinationals leads these firms to prefer liberal trade policies over protectionism (Strange, 1985).

These arguments are appealing because they model firm level preferences as a function of three seemingly parsimonious variables: firm health, level of multinationality, and export dependence. Several interesting questions arise, however, when these hypotheses are examined in the context of the international airline industry. The assumption made by Milner (1988) and others that export dependence is positively correlated with preferences for trade liberalization seems to fall apart in the face of preliminary evidence from the U.S. airline industry. In the wake of domestic deregulation, carriers whose business was either exclusively domestic or exclusively international were either opposed or ambivalent to efforts aimed at liberalizing the international market. 
Studies by McKeown (1984) and others that focus on firm health and argue that troubled firms will seek protection seem to falter when applied to the airline market. Again, using preliminary analysis of the U.S. industry, firms in financial distress often pursue both commercial and political strategies that are seemingly more in line with liberalization. Finally, the notion that multinationality increases the desire for liberal policies seems tenuous in the context of the recent proliferation of agreements between American and European airlines. On the surface, these alliances appear to be a move toward liberalization. However, a more careful examination of these firm strategies reveals that such arrangements can, in fact, be protectionist. Joint marketing and operating arrangements allow airlines to rationalize the market and deter competitors from entry. By far the most important type of alliance is code sharing, which involves placing one carrier's two letter designator code on another carrier's flight, allowing these airlines to operate as a seamless service network. This creates global carriers without necessarily enhancing competition or furthering liberalization.

Liberalization, Globalization, and Competition in the International Airline Industry

We are left to speculate why the hypotheses described above do not hold when applied to the international airline market. At first glance, there is no reason to believe that airlines should operate or generate preferences uniquely. The puzzle is whether airlines are inherently different from other firms operating in the international political economy, or alternatively, whether the environment in which airlines operate shapes the relationships between the variables discussed above and firm preferences in ways that are not easily understood. A tempting explanation is simply that the special relationship between the airline industry and national governments produced a unique market structure in which firms never had to face the forces of competition until the 1980s. This account helps explain some of the preferences and strategies adopted by U.S. airlines, however, it leaves other important questions unanswered.

In the balance of this paper, we assess the development of the international airline industry and provide a new approach to understanding the linkages between politics and firm strategy in both domestic and international industries. Firm health, multinationality, and export-dependence are re-defined and incorporated into a new model of firm preferences. The model places these variables in the larger political and commercial contexts in which firms generate preferences. The model breaks firm behavior into two tracks, each with its own set of strategies. The tracks are political and commercial. The political track involves strategies and behavior designed to influence the political process in ways that meet the firms' interests. The commercial track involves strategies and behavior designed to meet the challenges of the increasingly competitive marketplace. Of course, these tracks are not separate in reality, but it is useful to separate them for the purposes of understanding how firms formulate preferences for different trade policies. 


\section{A Model of Airline Strategies}

Time is an important, yet often overlooked, variable in the process of influencing policy formation. It takes some amount of time for a firm or any other interest group to mount an effective campaign to influence policy. On rare occasions attempts to influence governmental policy work quickly and effectively, but in most cases the attempts are either lengthy or fail all together (Baumgartner \& Jones, 1993). We are especially interested in the latter case, where the process of influencing the government to implement a seemingly favorable policy, or in this case to aggressively negotiate the expansion of "open skies," is difficult and time-consuming. The process of changing international airline policy is politically sensitive since it involves a clash of powerful interests that makes change difficult under the best of circumstances (Milner, 1988).

\section{Figure 1}

The Interaction of Political and Commercial Strategies

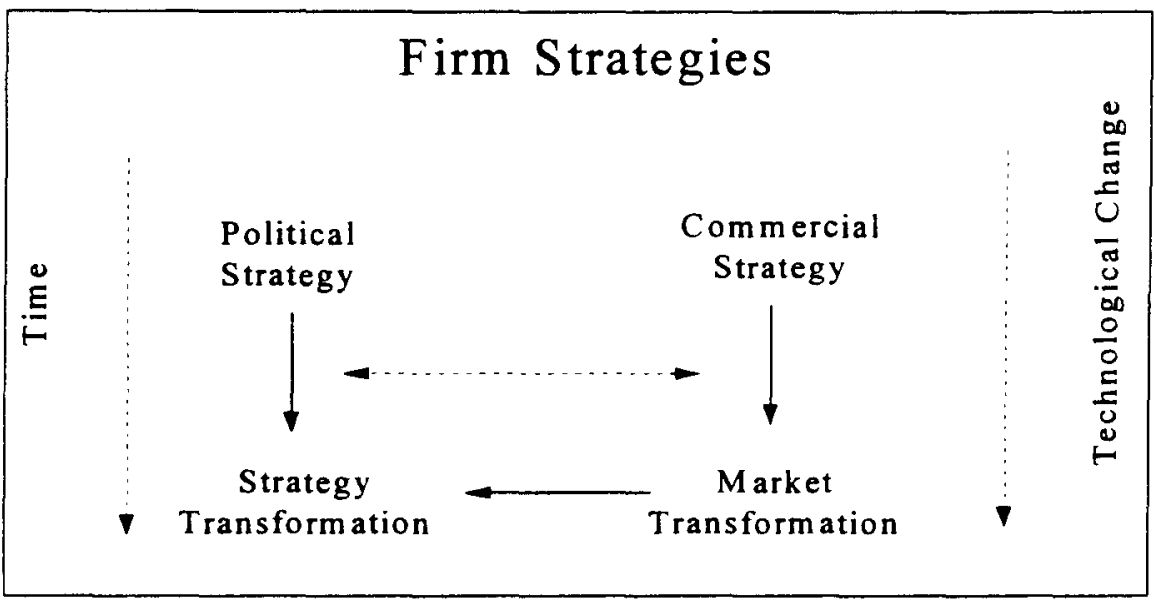

The model presented in Figure 1 depicts the process by which the transformation of strategies and decision making environments occurs over time. This framework is employed later in the paper to illustrate the dual track strategic decisions made by several U.S. and European airlines in recent years. Time and technological change are important factors in shaping firm strategies which, in turn, alter the market and subsequent firm behavior. The diagram suggests that over time commercial strategies may alter the market and a firm's policy preferences.

As governments are either unwilling or unable to implement a firm's preferred policies, the firm must continue to meet the demands of the marketplace and respond to the competitive actions of other firms in the oligopolistic airline market. The longer it takes for 
the government to implement favorable policy, the more likely a firm is to adopt survival strategies that deal with the realities of the marketplace, even if these strategies are in opposition to the preferred policy sought on the political track. In the end, the commercial strategies adopted to address the demands of the market may actually create a situation in which the firms' political strategies are transformed because of their weak financial condition or because of the nature of the market has been transformed by technological and marketing innovations.

The critical feature of this model is how time interacts with the preferences of the firms and their ability to influence the political process. Needless to say, market structure also affects the eventual outcomes by shaping the strength and needs of individual firms as they attempt to alter policy. The factors traditionally thought to shape firm preferences: firm health, multinationality, and export dependence take on new meaning as firms attempt to secure favorable policies via the political track while at the same time pursuing commercial strategies that include joint marketing and operating alliances with foreign airline partners.

\section{Competition in the International Air Travel Market}

In contrast to all the debate and fanfare over domestic deregulation, it is interesting to note that Congress enacted the International Airline Competition Act of 1979 with little publicity. This event marked a third attempt to encourage and promote open competition, or "open skies" in the international airline market (Clarke \& Gourdin, 1994). American economic and political decision makers, even those who worried about the negative effects of domestic deregulation, believed U.S. airlines would dominate a liberalized international air travel market. The reality has been somewhat mixed. America's traditionally dominant international carriers, Pan Am and Trans World Airways (TWA), discovered quickly that their initial optimism was unwarranted. The U.S. government was not successful in opening the world's skies quickly. More importantly though, the once proud international carriers found that the combination of domestic deregulation and international liberalization left them unable to effectively compete against some of their stronger American competitors. Pan Am, for example, lacked the domestic feeder network to transport passengers from various cities throughout the U.S. to international gateway airports from which Pan Am provided scheduled service to Europe and other parts of the world. Passengers who might have traveled on a transnational carrier to connect with Pan Am for the international leg of their journey were no longer forced to endure the hassles of changing carriers and opted for single carrier service from their original points of departure to the cities of Europe.

Domestic deregulation and the widespread adoption of hub and spoke route. structures required airlines to expand services quickly. Financially weak carriers chose to cut fares, causing fare wars, which are a classic characteristic of oligopolistic market structures. Consequently, the entire domestic industry was forced to offer services at prices which were below fully allocated costs, which is not a viable long-run strategy. This 
unsustainable fare structure forced carriers to compete in other ways, namely, through incentive programs such as frequent flyer programs that give travelers free flights after the accumulation of a predetermined number of paid miles. The first frequent flyer program, AAdvantage, was introduced by American Airlines in 1981 (Levine, 1987).

Several U.S. airlines struggled for survival in the face of this fierce competition. Financial problems forced some carriers to seek foreign assistance through joint equity arrangements. Other carriers, decidedly impatient with the government's efforts, sought code sharing (the computerized linking of separate airlines into a somewhat seamless system of computerized reservations and transportation service) and other joint operating agreements with foreign carriers to pry the skies open. The result is a complex commercial and political environment.

The events that occurred in the U.S. airline industry during the 1980 s were certainly not ignored by foreign competitors, particularly in Europe. The European Union's (EU) goal of an open internal market for members is confounded by the fact that no member abrogates its air sovereignty by membership in the EU. During the 1980 s there was a tendency towards more liberal bilateral air services agreements, however, not the "open skies" type of deregulatory policy called for in the International Air Competition Act in 1979 (Bueno de Mesquita \& Stokman, 1995). The EU has enacted several changes including the removal of some traditional protectionist policies, but most of the changes only affect airline services within the European Union. Not surprisingly, many proposed EU policies and those now in effect favor European flag carriers at the expense of large U.S. carriers such as American, Delta, and United Airlines (Clarke \& Gourdin, 1994). Nonmember access to European airports remains an important and divisive issue (Doganis, 1994).

\section{Case Studies}

The following cases demonstrate that the commercial behavior of U.S. airlines in the wake of deregulation combined with European resistance to open skies creates a Faustian bargain for some U.S. carriers. Those in poor financial condition chose innovative commercial strategies to cure their ills, while those in prime condition found political change a fleeting possibility. In the end, virtually all airlines, regardless of policy preference and financial health chose some form of globalization strategy that may actually make liberalization more difficult to achieve.

We examine four cases to illustrate the interaction of political and commercial strategies over time and in the context of changing technologies and market structures. The first two cases involve ailing U.S. airlines arid their attempts to enhance their prospects for survival while not losing out on the opportunity for a share of the global air travel market. The other cases involve U.S. carriers whose financial survival was not in doubt, but whose management believed they were not being given sufficient access to foreign markets to effectively exploit their comparative advantage over foreign carriers. 
Northwest Airlines

Deregulation of the domestic airline market brought a number of unanticipated consequences. One of the most important was the dramatic increase of debt taken on by American carriers that hoped to expand quickly to take advantage of economies of scope in the newly competitive domestic market. These strategic moves were not problematic in and of themselves, but the combination of inexperienced management, fierce competition, and enormous debt loads at high costs of capital left some carriers in precarious financial positions despite significant and seemingly successful operations. The merger mania that gripped American business in the 1980s fueled by the emergence of risky high-yield "junk" bonds was particularly problematic for the U.S. airline industry which is highly cyclical.

Northwest Airlines (NWA) falls squarely into this category. Like so many other American corporations in the 1980s, NWA attempted to expand its operations by growing through merger and acquisition. NWA completed a merger with Republic Airlines (which had itself taken over both Hughes Air West and Southern Airways in the early 1980s) in 1985 through a leveraged buyout (LBO). LBOs are typically financed through the sale of high-yield or "junk" bonds. On its face, this was not a bad strategy considering that deregulation and the evolution of the hub and spoke system meant that the carriers that could move quickly to expand services would reap long term benefits of larger market shares and dominant competitive positions. A few years later, Northwest found itself in a takeover battle with a group of California investors headed by real estate developer Albert Checchi. Checchi's group was ultimately successful in its takeover of Northwest, with junk bonds providing the primary source of funds for the takeover (Lipin \& Quintanilla, 1995).

Even well-managed firms meet with disaster after assuming enormous debt loads. This was especially true in the airline industry where the management of many U.S. carriers were not prepared for the rapid decision making dynamic of an openly competitive market. Decades of regulation protected mediocre managers and dampened the effects of poor decisions. In fact, economic regulation removed many of the incentives for efficient performance. Northwest, like so many other U.S. carriers found itself ill-equipped to handle the rigors of competition. In the end, its commercial strategy of expansion through increased debt altered the way in which NWA entered the competition for position in the international air travel market (Lipin \& Quintanilla, 1995).

One might expect that NWA launched a similarly aggressive scheme to capture a share of the international market. Two issues prevented this from happening. First, expansion in the international market requires access to airports and foreign airspace. Even as air space restrictions were diminishing through bilateral negotiations, a lack of access to airports, because of restrictions on access to gates or slots made expansion difficult. Moreover, NWA's financial difficulties made growth an onerous proposition. So while the airline initially preferred open competition in the international market, it found alternative arrangements commercially imperative. 
Figure 2

The Interaction of Strategies in the KLM - NWA Agreement

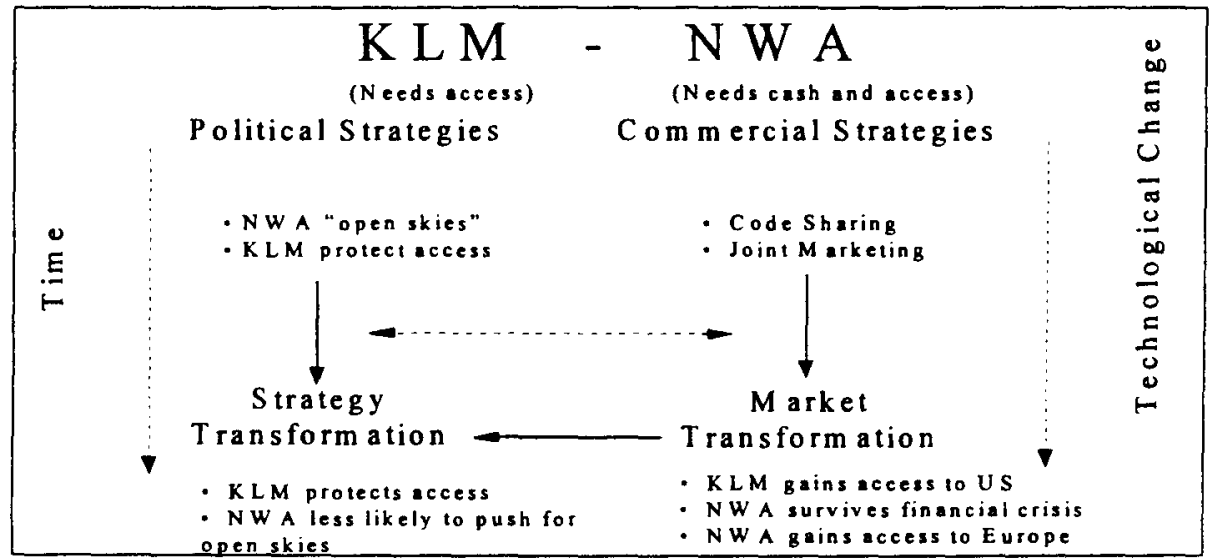

NWA's subsequent commercial strategy was to form an alliance with KLM, a Dutch carrier, who would take part ownership of the troubled carrier through a $\$ 400$ million investment in 1989 (GRA, Incorporated, 1994). The investment was necessary to keep NWA from joining other troubled U.S. carriers seeking bankruptcy protection. KLM received access to NWA's hubs in Minneapolis, Detroit, and Boston. Eventually, the arrangement was formalized into a joint marketing and code sharing alliance that allowed NWA and KLM to list each other's flights on computer reservation systems. A bilaterally negotiated "open skies" agreement between the Netherlands and the U.S. was signed in 1992 that allowed unlimited code sharing for Dutch and U.S. carriers (GRA, Incorporated, 1994). While the agreement did not specifically name the KLM-NWA agreement as its motivation, the reason for the agreement is clear. It is not unusual for general bilateral agreements between two countries to address the specific demands or needs of a single carrier. The recent "minideal" between the U.S. and Great Britain is a case in point where United Airlines was granted a Chicago-London route.

NWA gained an important infusion of cash through the agreement. It also gained access via code share to more European destinations, even though it would stop actual NWA service to at least seven cities previously served by Northwest jets (U.S. GAO, 1993). KLM assumed responsibility for delivering NWA passengers to these cities as well as other traditional KLM destinations. KLM gained considerable access to the U.S. market via the joint operating agreement. It also gained a voice in the operation of a major U.S. carrier. 
Perhaps more importantly than the individual gains to either airline is the positive impact the new operating arrangement had on KLM-NWA as an aggregate body. KLM was cash rich, but access poor before the deal with NWA. It could offer considerable access to major European destinations, but without better access to the U.S. it would likely fail in competition with other European and U.S. carriers. NWA was cash poor, but access rich, especially in terms of its dominant hubs at Minneapolis and Detroit. The resulting arrangement made good sense for both parties and provided an even more dramatic side benefit. The joint operating agreement effectively created a global carrier. KLM's links to Europe and NWA's links to the U.S. and Asia make the aggregation of the two carriers a dominant force in the international air travel market. Competitors in the U.S. or Europe that do not have similar economies of scope or market access will find it difficult to compete or even enter the market against such formidable competition.

Clearly, NWA is in favor of globalization. Such a commercial strategy worked handsomely to prevent the airline from demise. It is unlikely, however, that this enthusiasm will translate into support for further liberalization for a number of reasons. First, despite the multinationality of NWA-KLM's joint operating agreement, it is not in their interest to aggressively pursue "open skies" that will allow more open competition in the international market. Their agreement is tailored to the commercial and political realities of several years ago when the only way for access to foreign markets in any meaningful sense was through such arrangements. Now that a commitment has been made, especially the KLM investment, it is unlikely for either airline to support American Airline's bid for complete and open access to all markets. Globalization in this case increases the multinational character of the operations and the ownership structure, but actually decreases the demand for liberalization of the market. The commercial strategy taken by KLM and NWA altered the market structure, which in turn effectively altered the political strategy of each firm as it sought government support for favorable policies in the international airline market.

\section{USAir}

Northwest Airlines was by no means the only U.S. carrier that found itself in need of financial assistance. For many of the same reasons that plagued NWA, USAir found itself in dire straits at the beginning of the 1990s. USAir also joined in the merger mania that characterized U.S. industry in the 1980s by acquiring both Piedmont Airlines and PSA in the mid-1980s to attain "critical mass" and to enjoy the economies of scale and scope that conventional wisdom of the era deemed necessary for survival (Levine, 1987). Rapid expansion and unexpected difficulties resulting from combining the vastly different corporate cultures, varieties of aircraft, and operating procedures of the acquired airlines caused serious problems for USAir management. The fierce price wars of the $1980 \mathrm{~s}$ caught up to the airline and left it on the teetering on the brink of bankruptcy. To the dismay of many industry and government actors, USAir found a white knight in the form of British Airways. The subsequent equity and operating alliance between the two airlines illustrates 
further how the political strategies of air carriers can be confounded by commercial realities and changes in market structure.

In 1991, the U.S. and Great Britain negotiated a bilateral agreement that permitted broad code sharing arrangements between the nations' carriers (GRA, Incorporated 1994). At the time, British Airways made no moves to initiate such an arrangement with a U.S. carrier, waiting instead for a more attractive arrangement. Its strategy was shaped in part by the intense pressure being exerted by American Airlines and United Airlines on the U.S. Government to force the British to open up Heathrow Airport to U.S. carriers. These airlines believed that a truly open arrangement would allow them to take advantage of their more efficient operations to compete effectively against the British and other European carriers. Many European airlines were suffering enormous losses, requiring significant cash infusions from their national governments to remain aloft.

Figure 3

The Interaction of Strategies in the BA - USAir Agreement

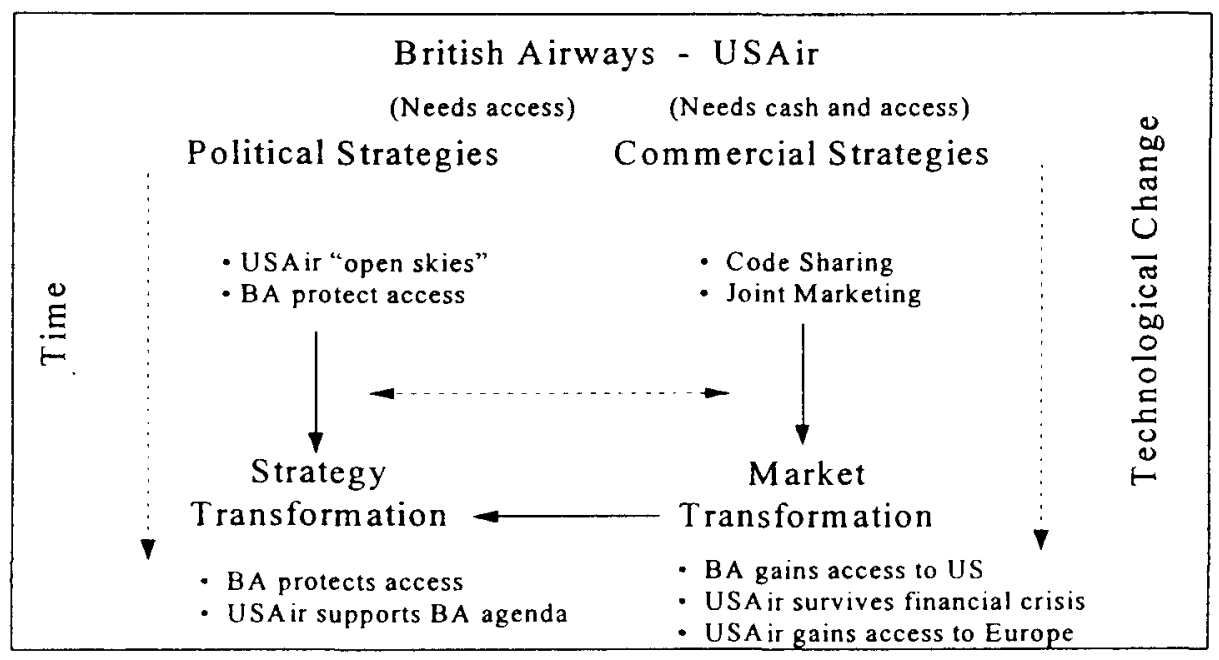

While the British government, and other European governments, resisted open competition, carriers like British Airways desperately sought ways to maximize their dominant position in Britain and the broader European market. Code sharing offered the best answer. The stronger U.S. carriers were wary of such an arrangement because they still held out hope for open skies and real competition. Small carriers didn't offer the scope of service that only a true hub and spoke operation could provide. Since Northwest was already taken, British Airways selected USAir as its partner. 
Just as KLM rescued NWA with a cash infusion, British Airways saved USAir. An initial investment of $\$ 750$ million that would give British Airways a $44 \%$ stake in the carrier and $21 \%$ of its voting stock was tendered, but withdrawn after well-publicized criticism by industry and political leaders. Eventually, the deal was consummated in the form of a $\$ 300$ million investment and a $19.9 \%$ voting stake in the U.S. carrier (Newhouse, 1993). The joint operating agreement is similar in many ways to the one struck between KLM and NWA, but there are striking differences as well. British Airways currently holds a $24.6 \%$ voting stake in USAir, which is just below the legal limit of $25 \%$ foreign ownership. Perhaps more importantly, British Airways also hold three USAir board seats, giving it considerable influence in the operation of a large U.S. airline (GRA, Incorporated, 1994).

British Airways clearly dominates the arrangement. The British carrier essentially makes all policy choices regarding service provided in the joint agreement and how code sharing will be handled. USAir does not put its code on British Airways flights. As a result the arrangement appears to be a one way street in terms of marketing and service. Whereas the KLM-NWA arrangement is a joint marketing plan, the British Airways-USAir deal is much more like a feeder or subsidiary relationship typical of the arrangement between large U.S. carriers and various regional airlines that serve as feeders for their larger code sharing partners.

The arrangement between USAir and British Airways suggests conclusions similar to those reached in the analysis of the KLM-NWA case. Both airlines faced political and commercial conditions that necessitated a new strategy. For USAir, the strategy was driven by the need for cash as well as access to foreign markets. For British Airways, the strategy was driven by the need for access to American markets, while protecting its domestic market from potential American competition. At the very least British Airways sought a strategy that would place it in a much more competitive position if the political climate changed at some point in the future. In the end, however, British Airways gained access to the U.S. market and a high measure of control over a major U.S. carrier while USAir ensured its survival for at least a few years. More importantly, the arrangement satisfies the needs of both carriers and establishes a global alliance that will work against further liberalization of the international airline market.

\section{American Airlines}

American Airlines remains the staunchest industry critic of the international code sharing and joint operating agreements described above. American argues that the British and Dutch gained valuable access to the U.S. market without reciprocal access for U.S. carriers in the European market. The airline suggests that political pressure to save jobs and service to key hubs in the U.S. forced the government to support the European bailout of two major U.S. carriers ("Mixing of U.S...", 1992). The deals effectively limit competition in the U.S. by keeping carriers aloft that might easily have followed Pan Am and Eastern into the grave. Further, the alliances limit competition in Europe by removing the most 
attractive bargaining chip available to the U.S. government in "open skies" negotiations: access to the huge U.S. market.

American's political strategy involves continued pressure on the DOT and other U.S. policy makers to recognize the asymmetries of the KLM-NWA and British AirwaysUSAir deals. Commercially, American has negotiated a number of code share agreements with several foreign airlines, but remains committed to its demands for open access and competition in Europe. The problem is that as the NWA and USAir code share deals take on a more permanent character, it becomes difficult for American to resist jumping on the joint operating bandwagon to insure that it isn't closed out or left in a weak position in the event of real liberalization of the international market. Unfortunately, such moves tend to reinforce the structure of the market that makes code sharing and joint marketing programs the dominant tools to compete and limit competition in international air travel.

\section{Delta Airlines}

Delta Airlines is a strong competitor in the international airline market and a proponent of liberalization. Delta has a number of code sharing arrangements, but these primarily work to supplement Delta's broad service network. Recently Delta initiated an innovative strategy with Virgin Atlantic Airlines. In a twist on the standard code share scheme, Delta would market seats on Virgin Atlantic after buying them from Virgin at wholesale prices. The strategy gives Virgin access to Delta's large service network and gives Delta access to London's Heathrow Airport. Delta is quick to point out that this is not a permanent solution and it would rather have open access and real competition at Heathrow and other European destinations. Nevertheless, the deal has been struck and further establishes such joint operating agreements as the standard way of doing business in the international airline market (Fuhrman, 1995).

Delta, like American, is healthy and wants open competition, yet finds the political track unproductive. While it continues to push for liberalization it is forced to take globalization measures that may very well make liberalization less likely in the near future. Code sharing by American and Delta lend support to that tactic as an acceptable strategy for globalizing the market, thus giving tacit support for the NWA and USAir deals that have dramatically restructured the market.

\section{Conclusion}

We draw several conclusions from this preliminary research on the international airline industry. First, the standard dichotomy of protection versus liberalization is not as useful as it might be in other industries. This is because airlines can pursue globalization strategies that appear to support liberalization when in fact such strategies tend to erect barriers to liberalization and reinforce anti-competitive practices. A second conclusion is that the dual track model provides some useful clues as to why firms that we would expect to prefer open competition resort to code share and joint operating agreements that are 
likely to make liberalization more difficult. This seems puzzling when considering firm preferences and behavior in the traditional endogenous tariff framework, but when firm behavior is considered in both the political and commercial contexts simultaneously, such behavior appears almost inevitable. The longer it takes for governments to liberalize the international air travel market, the more likely these carriers are to pursue commercial strategies that protect their short-term interests.

Finally, we conclude that a better understanding of the prospects for real liberalization and competition in the airline industry may help answer similar questions about other service industries. Our finding that globalization and joint operating strategies might actually serve anti-competitive and protectionist interests should be a sobering conclusion for policy makers and consumers that support globalization strategies as the means to more efficient firms and industries in the future.

This study demonstrates that globalization strategies need more scrutiny by academics and policy makers. This is especially true in light of current deliberations over raising the limit on foreign ownership of U.S. carriers from $25 \%$ to $49 \%$. While such plans may resolve the immediate financial crises of some U.S. carriers and preserve jobs and other politically important benefits, there are dangers associated with further opening the U.S. market without reciprocal liberalization in Europe and other regions.

\section{References}

Baldwin, R. (1986). The Political Economy of U.S. Import Policy. Cambridge: MIT Press. Baumgartner, F. R. \& B. D. Jones. (1993). Agendas and Instability in American Politics. Chicago: University of Chicago Press.

Brock, W. \& S. Magee. (1978). The economics of special interest politics: case of the tariff. American Political Science Review 68, 246-50.

Bueno de Mesquita, B. \& F. Stokman. (1995). European Community Decision Making. New Haven: Yale University Press.

Clarke, R. L. \& K. N. Gourdin. (1994). European aviation reform and U.S. international airlines. Transportation Quarterly. 48, 267-73.

Destler, I. M. \& J. Odell. (1987). Anti-Protection: Changing Forces in United States Trade Politics. Washington, D.C.: Institute for International Economics.

Doganis, R. (1994). The impact of liberalization on European airline strategies and operations. Joumal of Air Transport Management. 1, 15-25.

Ferguson, T. (1984). From normalcy to new deal. International Organization 38, 40-94.

Furhman, P. (1995, January 2). Brand-name Branson. Eorbes. 41.

GRA, Incorporated. (1994). A Study of International Code Sharing. Washington, D.C.: U.S. Department of Transportation.

Gialloreto, L. (1988). Strategic Airline Management: The global war begins. London: Pitman Publishing.

Hillman, A. L. (1982). Declining industries and political-support protectionist motives. The American Economic Review . 72, 1180-1187. 
Levine, M. E. (1987). Airline competition in deregulated markets: theory, firm strategy, and public policy. Yale Journal on Regulation. 4, 393-494.

Lipin, S. \& C. Quintanilla. (1995, May 25). Pair wins big on investment in Northwest. Wall Street Journal. C1.

Magee, S. P. (1994). The political economy of trade policy. Surveys in International Trade, Oxford: Blackwell.

Magee, S. P., W. A. Brock, and L. Young. (1989). Black Hole Tariffs and Endogenous Policy Theory: political economy in general equilibrium. New York: Cambridge University Press.

McKeown, T. J. (1984). Firms and tariff regime change: explaining the demand for protection. World Politics. 36, 215-233.

Milner, H. V. (1988). Resisting Protectionism: Global Industries and the Politic of International Trade . Princeton: Princeton University Press.

Mixing of U.S. foreign carriers alters market. Wall Street Journal. December 21, 1992, B1.

Nelson, D. (1988). Endogenous tariff theory: a critical survey. American Journal of Political Science. 32, 796-837.

Newhouse, J. (1993, January 18). The battle of the bailout. The New Yorker. 44.

Strange, S. (1985). Protectionism and world politics. International Organization. 39, 23360.

United States Department of Transportation. (1994). U.S. International Aviation Statement. Washington, D.C.: U.S. Government Printing Office.

United States Government Accounting Office. (1992). Airline Competition: Impact of Changing Foreign Investment and Control Limits on U.S. Airlines. GAO/RCED-937. Washington, D.C.: U.S. Government Printing Office.

United States Government Accounting Office. (1993). International Aviation: Measures by European Community Could Limit U.S. Airlines' Ability to Compete Abroad. GAO/RCED-93-64. Washington, D.C.: U.S. Government Printing Office. 